\title{
Quality Evaluation of Beef Preserved With Food Grade Organic Acids at Room Temperature
}

\author{
Eniolorunda O. O. ${ }^{1}$, Apata E. S. ${ }^{1}$, Ogunlesi O. E. ${ }^{1}$, \& Okubanjo A. O. ${ }^{2}$ \\ ${ }^{1}$ Meat Science Laboratory, Department of Animal Production Olabisi Onabanjo University, Ogun State, Nigeria \\ ${ }^{2}$ Department of Agriculture and Industrial Technology, Babcock University, Ogun State, Nigeria \\ Correspondence: Apata E. S., Meat Science Laboratory, Department of Animal Production Olabisi Onabanjo \\ University, Ogun State, Nigeria. E-mail: ebuoluapata2008@yahoo.com
}

Received: March 18, 2014 Accepted: May 28, 2014 Online Published: July 30, 2014

doi:10.5539/jfr.v3n5p120 URL: http://dx.doi.org/10.5539/jfr.v3n5p120

\begin{abstract}
The objective of this study was to investigate the effects of three common food grade organic acids - citric, acetic and ascorbic on quality properties of fresh beef preserved for 14 days. $1 \mathrm{~kg}$ of fresh beef (thigh muscle) of White Fulani cow was purchased at Ayetoro market in Yewa North local government Area of Ogun State and was divided into 4 equal parts of $250 \mathrm{~g}$ per treatment replicated three times. The acids were purchased at Federal Institute of Industrial Research Oshodi (FIIRO) Lagos. 5\% each of the organic acid was prepared and constituted an experimental treatment, freezing was used as control. Thus: $\mathrm{T} 1=$ Freezing (control), $\mathrm{T} 2=$ Citric acid, $\mathrm{T} 3=$ Acetic acid, $\mathrm{T} 4=$ Ascorbic acid. $10 \mathrm{ml}$ of each organic acid solution was injected into $250 \mathrm{~g}$ fresh beef with a needle and syringe and immersed in the same solution in covered plastic containers, stored at room temperature $\left(27^{\circ} \mathrm{C}\right)$.

The results showed that most of the physicochemical properties of the preserved beef were better $(\mathrm{P}<0.05)$ in treatment 3, also. Lipid oxidation and microbial values were lower $(\mathrm{P}<0.05)$ in the same treatment. However, acceptability of beef in treatment 3 was lower $(\mathrm{P}<0.05)$ because colour and flavour scores beef were lower $(\mathrm{P}<$ 0.05). It was suggested therefore, that lower concentrations of acetic acid be tested in a separate study to ascertain concentration level that will confer higher colour flavour and acceptability scores on beef since acetic acid favoured almost all tested properties and of preserved beef in this study.
\end{abstract}

Keywords: beef, food grade, organic acids, quality, room temperature

\section{Introduction}

Beef when fresh is high in nutritional value in that it is rich in vitamins and minerals and provides an important source of high quality protein (Mohamed et al., 2008). It has unique biological and chemical attributes and its nutrient composition predisposes it to deterioration due to microbial growth and rancidity development, hence its shortened shelflife (Houben et al., 2000). The shelf-life represents the useful storage time of meat or meat product, beyond this period, changes in smell, colour, taste and texture make them unacceptable. It is affected by several factors such as temperature, $\mathrm{pH}$, oxygen, pressure, light and oxidation (Shahidi, 1994). Different types of pathogenic microorganisms may be introduced into and on the surface of fresh beef during slaughtering and processing, which cause rapid spoilage, and great loss of valuable protein, therefore, interventional procedures have been used to decontaminate the meat (Stopforth \& Sofos, 2006). One of such interventional procedures is the use of organic acids. Since fresh beef spoilage results from the activity of mixed populations of microorganisms, food grade organic acids can be used as a single or in combination for effective reduction of spoilage due to pathogenic microorganisms - (Lebert et al., 2005). Solutions of organic acids (1-5\%) such as lactic, acetic, citric, ascorbic, propionic fumaric and tartaric acids are the most frequently used chemical interventions for both beef and lamb dressing (Acuff, 2005). Acetic acid is a mono carboxylic acid with a pungent odour and taste known as vinegar which has antimicrobial capabilities due to its ability to lower the $\mathrm{pH}$ and cause instability of bacterial cell membrane (Ransom et al., 2003). Citric acid is a 2-hydoxy-1,2,3-propane tricarboxylic acid (white powder) extracted from juice of acidic fruits capable of inhibiting the growth of bacteria, yeast and moulds (Dubal et al., 2004), while L-ascorbic acid is slightly soluble in water and has antimicrobial capabilities like other organic acids (Wicklund et al., 2005). These three organic acids (acetic, citric and L-ascorbic) could be used in preserving fresh beef or any other types of fresh meat in rural areas of 
developing countries like Nigeria where electricity supply is still epileptic since they are common and can prolong the shelflife of fresh meat up to eleven days in refrigerated temperature (Dubal et al., 2004).

There is inadequate information in literature concerning the consequences of preserving fresh beef meat directly in organic acids at room temperature. Therefore, this study was conducted to evaluate the potentials and effects of the three food grade organic acids on quality characteristics of fresh beef.

\section{Materials and Methods}

\subsection{Location of Study}

This study was conducted in the Meat Science Laboratory of the Department of Animal Production, OlabisiOnabanjo University, Yewa Campus, Ayetoro, Ogun State.

\subsection{Meat Samples}

One kilogramme of fresh beef (Longissimu sdorsi) of White Fulani cow was purchased and used for this study. It was divided into 4 equal parts of $250 \mathrm{~g}$ per treatment and was replicated three times.

\subsection{Organic Acids}

The dietary organic acids tested were citric, acetic and ascorbic acids. They were purchased from Federal Institutes of Industrial Research, Oshodi, (FIIRO) in Lagos. 5\% of each organic acid was prepared with distilled water. Each of the organic acid constituted an experimental treatment, while cold preservation by freezing was used as control treatment as arranged below:

$\mathrm{T} 1($ control) $=$ Freezing preservation

$$
\begin{aligned}
& \mathrm{T} 2=\text { Citric Acid } \\
& \mathrm{T} 3=\text { Acetic Acid } \\
& \mathrm{T} 4=\text { Ascorbic Acid } \\
& 2.4 \text { Preservation of Meat }
\end{aligned}
$$

$10 \mathrm{ml}$ of each tested solution of $5 \%$ organic acid was injected with the aid of a needle and symige into $250 \mathrm{~g}$ fresh beef meat sample and was immersed in the same solution of each organic acid in a plastic container with a lid and stored at room temperature $\left(27^{\circ} \mathrm{C}\right)$ in a netted box for 14 days ( 2 weeks) after which the following meat parameters were determined.

\subsection{Raw Meat Colour}

This was determined with visual method following the procedures of AMSA (1991). Meat samples from each treatment were displayed in a tray and a 10-member panel was used to score the meat based on colour intensity (redness) and homogeneity of the meat samples using a scale ranging from 1-8 with higher scores representing a more attractive and homogenous red colour.

\subsection{Cooking Loss and Thermal Shortening}

Cooking loss was measured by removing approximately $10 \mathrm{~g}$ and $6 \mathrm{~cm}$ long meat sample from each treatment, wrapped in air tight polythene bags with a thermometer $\left(110^{\circ} \mathrm{C}\right)$ inserted in the meat and cooked in water in a pre-heated cooking pot for 20 min. on and adjustable Pifco Japan Electric "hot" plate Model No. ECP 2002 until the geometric centre of the meat samples was heated to $72^{\circ} \mathrm{C}$ (Malgorzata et al., 2005). Meat samples were removed from the pot and cooled to room temperature $\left(27^{\circ} \mathrm{C}\right)$. They were reweighed and the difference in weight recorded as percentage cooking loss as follows:

$$
\text { Cooking loss }=\frac{\text { Initial wt. of meat }- \text { Final wt. of meat }}{\text { Initial Wt. of meat }} \times 100
$$

Thermal shortening of the meat samples was measured with the same meat samples used to measure cooking loss. The lengths of meat samples were remeasured after cooking and cooling, the difference in length was expressed as thermal shortening following the modified method of Malgorzata et al. (2005).

Thus:

$$
\text { Thermal shortening }=\frac{\text { Initial length of meat }- \text { Final length of meat }}{\text { Initial length of meat }} \times 100
$$




\subsection{Percentage Cooking Yield}

This was obtained by substracting the value of percentage cooking loss from $100 \%$ and the remainder recorded as the percentage cooking yield according to Omojola (2008).

Thus: Cooking yield $=100 \%-\%$ cooking loss

\subsection{Drip Loss}

This was determined following the procedures of Insausti et al. (2001). Weight of an empty polythene bag was taken $(\mathrm{Wp})$ Meat sample $(10 \mathrm{~g})$ was weighed and put into the bag $(\mathrm{Wp}+\mathrm{M})$ and stored in a refrigerator at $4{ }^{\circ} \mathrm{C}$ for $48 \mathrm{~h}$. The meat sample was removed from the refrigeration and the weight of the bag plus the juice drained by the meat sample were measured $(\mathrm{Wp}+\mathrm{j})$. drip loss was expressed as percentage of the initial weight of the meat sample, thus:

$$
\text { Drip loss }=\frac{(W p+j)-(W p)}{(W p+m)-(W p)} \times 100
$$

\subsection{Water Holding Capacity (WHC)}

An approximately $1 \mathrm{~g}$ of meat sample from each treatment was placed between two $9 \mathrm{~cm}$ Whatman No 1 filter papers (Model C, Caver Inc. Wabash, USA). The meat sample was pressed between two $10.2 \times 10.2 \mathrm{~cm}^{2}$ plexiglasses at about $35.2 \mathrm{~kg} / \mathrm{cm}^{3}$ absolute pressure for 1 minute with a vice (Suzuki et al., 1991). The meat sample was removed and oven dried between $100-105^{\circ} \mathrm{C}$ for $24 \mathrm{~h}$ to determine the moisture content of the meat sample. The amount of water released from the meat sample was measured indirectly by measuring the area of filter paper welted relative to the area of pressed meat sample.

Thus:

$$
\mathrm{WHC}=\frac{100-(\mathrm{Aw}-\mathrm{Am}) \times 9.47}{\mathrm{Wm} \times \mathrm{Mc}} \times 100
$$

Where:

$\mathrm{Aw}=$ Area of water released from meat sample $\left(\mathrm{cm}^{2}\right)$

$\mathrm{Am}=$ Area of meat sample $\left(\mathrm{cm}^{2}\right)$

$\mathrm{Wm}=$ Weight of meat sample $(\mathrm{g})$

$\mathrm{Mc}=$ Moisture content of meat sample (\%)

$9.47=$ A constant factor.

\subsection{Shear Force}

Weighed meat samples from each treatment ( $10 \mathrm{~g})$ was wrapped in polythene bags and cooked in a pre-heated cooking pot for $20 \mathrm{~min}$ on an adjustable Pifco Japan Electric hot plate Model NECP 202 to an internal temperature of $72{ }^{\circ} \mathrm{C}$. They were removed and cooled to room temperature $\left(27^{\circ} \mathrm{C}\right)$ for $10 \mathrm{~min}$, reweighed, bagged and chilled at $4{ }^{\circ} \mathrm{C}$ for $18 \mathrm{~h}$. They were equilibrated to room temperature and $1.25 \mathrm{~cm}$ diameter cores parallel to muscle fibre orientation were removed with a coring device (Qiaofen \& Da-Wen, 2005). The meat samples were sheared at three locations with WarnerBratzler V-notch blade shearing instrument according to Honikel (1998) and average value of the three shearing was taken.

\subsection{Proximate Composition}

This was determined following the procedures of AOAC (2000). Moisture content of meat samples was obtained by drying $2 \mathrm{~g}$ of meat in an oven at $100-105^{\circ} \mathrm{C}$ for $24 \mathrm{~h}$ until a constant weight was reached. Crude protein was determined by using Kjedahl method which comprised, digestion, distillation and titration of the distillate. Crude protein value was obtained by converting nitrogen $(\mathrm{N} \%)$ content with a constant (6.25) crude protein was thus obtained as $(6.25 \times \mathrm{N} \%)$. Fat was determined with soxhlet extraction method using petroleum ether. Ash content of the meat sample was determined by igniting $2 \mathrm{~g}$ of it in a Muffle furnace set between 550 and $600{ }^{\circ} \mathrm{C}$ for $4 \mathrm{~h}$ until the ash was formed and was weighed.

\section{$2.12 \mathrm{pH}$ of Meat}

This was taken after the preservation period of 14 days. $10 \mathrm{~g}$ of meat sample from each treatment was homogenized for $5 \mathrm{~min}$ with $90 \mathrm{ml}$ distilled water with a blender (plate $5 \mathrm{~mm}$ ) model 242, Nakai, Japan. The 
meat $\mathrm{pH}$ was measured with a potable $\mathrm{pH}$ meter Model H184 Micro Computer, Havanna Instruments, Romania (Marchiori \& deFelicio, 2003).

\subsection{Lipid Oxidation}

Lipid oxidation of meat sample from each treatment was determined with TBA and mPV methods; TBA - This was determined using the method described by Pensel (1990). $5.0 \mathrm{~g}$ of coarsely ground unrendered fat of meat sample from each treatment was placed in a polyethylene bag. An additional empty polyethylene bag was prepared as a blank. $50 \mathrm{ml}$ of a cold $\left(2 \pm 2{ }^{\circ} \mathrm{C}\right) 20 \%$ trichloroacetic acid (TCA) and $1.6 \%$ m-phosphoric acid mixture was immediately added to each meat in polyethylene bags and ground in a blender (Plate $5 \mathrm{~mm}$ ) (Model 242 Nakai Japan) for $2 \mathrm{~min} .50 \mathrm{ml}$ of cold $\left(2 \pm 2{ }^{\circ} \mathrm{C}\right)$ distilled water was added to each bag and blended for an additional $30 \mathrm{sec}$. The slurry was filtered through Whatman No. 1 fitter paper to remove the debris. $5.0 \mathrm{ml}$ of the filtered slurry was added to $5.0 \mathrm{ml}$ of freshly prepared $0.02 \mathrm{M}$ 2-thiobarbituric acid and mixed for $5 \mathrm{sec}$. The samples were subsequently stored in the dark at room temperature $\left(27^{\circ} \mathrm{C}\right.$ for $15 \mathrm{hrs}$ for the colour to develop. The colour was measured using a Gilford Response UV-VIS spectrophotometer (Ciba corning Diagnostic CO, Oberlin Ohio) at a wavelength of $530 \mathrm{~nm}$.

MPV - This was determined following the modified procedures of AOAC (2000). $50 \mathrm{~g}$ of unrendered fat of meat sample from each treatment was ground in a blender (Plate $5 \mathrm{~mm}$ ) (Model 242, Nakai, Japan) for $25 \mathrm{sec}$ and extracted with $30 \mathrm{ml}$ of ice cold $(3: 2 \mathrm{~V} / \mathrm{V})$ acetic acid: chloroform. The extraction was vigorously swirled to distribute the samples and reagents evenly. $0.5 \mathrm{ml}$ of saturated potassium iodide (K1) was added and mixed thoroughly. $30 \mathrm{ml}$ of distilled was added subsequently and the solution was mixed thoroughly. The mixture was allowed to stand for 5-10 mins, at room temperature $\left(27^{\circ} \mathrm{C}\right)$. The mixture was titrated with $0.01 \mathrm{M}$ sodium thiosulphate $\left(\mathrm{Na}_{2} \mathrm{~S}_{2} \mathrm{O}_{3}\right)$ gradually with vigorous shaking. $0.5 \mathrm{ml}$ of starch indicator $(1 \%$ starch $+0.3 \%$ chloroform) was added during titration. The sample was vigorously swirled and was allowed to stand for an additional 10 mins. The end point was established when the colour of the upper aqueous layer disappeared. The modified peroxide value (mPV) of samples was calculated with the formula;

$$
\mathrm{mPV}=\frac{(\mathrm{S})(\mathrm{N})(1000)}{\mathrm{W}}
$$

Where

$\mathrm{mPV}=$ modified peroxide value $(\mathrm{mEq})$

$\mathrm{S}=\mathrm{ml}$ of $\mathrm{Na}_{2} \mathrm{~S}_{2} \mathrm{O}_{3}(0.5)$

$\mathrm{N}=$ Normality of $\mathrm{Na}_{2} \mathrm{~S}_{2} \mathrm{O}_{3}(0.01)$

$\mathrm{W}=$ Weight of sample (g).

\subsection{Microbiology Evaluation of Meat}

$10 \mathrm{~g}$ of meat sample was removed from each treatment and blended with $90 \mathrm{ml}$ of $0.1 \%$ (W/V) peptone water for $60 \mathrm{sec}$. Dilutions were made in $0.1 \%$ peptone water and $1 \mathrm{ml}$ of undiluted homogenate of each sample was spread on duplicate petriplates. Bacterial counts were obtained from plates bearing colonies as follows: Aerobic plate count - on Plate count agar (DIFCO, USA) incubated at $32{ }^{\circ} \mathrm{C}$ for $48 \mathrm{~h}$ to isolate staphylococcus; Enterobacteriacease (Coliform) on violet Red Bile Glucose agar (DIFCO, USA) overlaid with the same medium and incubated at $37^{\circ} \mathrm{C}$ for $24 \mathrm{~h}$ to isolate Enterobacteria spp. and Lactic Acid Bacteria (LAB) on Lacto bacilli MRS Broth, Bacto agar and glacial acetic acid (pancreae) and incubated at $32{ }^{\circ} \mathrm{C}$ for $48 \mathrm{~h}$ to isolate lactobacillus spp. Counts were made and expressed in cfu/g of samples following the procedures of ICMSF (1986), APHA (1992) and AOAC (2000).

\subsection{Sensory Evaluation of Meat}

A 10-member semi-trained taste panel was used following the procedures AMSA (1995). The panellists were instructed on how to fill the sensory evaluation form. They were provided unsalted biscuits and water for use in between treatments meat samples. Meat samples were cooled after cooking for $20 \mathrm{~min}$ in labeled polythene bags with a thermometer $\left(110^{\circ} \mathrm{C}\right)$ inserted into the meat to an internal temperature of $72{ }^{\circ} \mathrm{C}$ using moist cooking. They were presented sequentially to the panellists on a clean saucer and meat sample from each treatment was evaluated independently. The panellists rated the meat samples on a 9-point hedonic scale on which $1=$ dislike extremely and $9=$ like extremely for colour, odour, flavour, tenderness, juiciness, ropiness, cohesiveness and overall acceptability. 


\subsection{Experimental Design and Statistical Analysis}

Completely randomized design was used for study. Data collected were subjected to analysis of variance (ANOVA) at ( $\mathrm{p}<0.05)$ using (SAS, 2002) and significant different among the means were separated with the aid of Duncan multiple range test of the same system.

\section{Results and Discussion}

All physical attributes except raw meat colour, Water Holding Capacity (WHC) and shear force were better ( $\mathrm{P}<$ 0.05 ) in treatment 3 than in other treatments (Table 1). Meat colour is enhanced by contact with oxygen as myoglobin is oxidized into oxymyoglobin (glooming). Meat sample in treatment 1 might have been in contact with oxygen in the freezer throughout the preservation period, whereas meat samples in treatments 2,3 and 4 might not due to the fact that the plastic container in which the meat samples were preserved with organic acids which were completely covered, this might have shielded oxygen penetration into the meat. The $\mathrm{pH}$ status of the meat which was higher $(\mathrm{P}<0.05)$ in treatment 1 than in other treatments could be due to high water holding capacity (Abril et al., 2002). Water holding capacity of meat samples was lower $(\mathrm{P}<0.05)$ in treatment 3 , probably as a result of low $(\mathrm{P}<0.05) \mathrm{pH}$ (Mohamed et al., 2008), most of the water in form of juice in the meat might have been lost into the acidic medium which could have led to higher $(\mathrm{P}<0.05)$ shearforce value due to shrinkage imposed on the meat sample by organic acid (Acetic acid).Since the $\mathrm{pH}$ of meat in treatment 1 was high $(\mathrm{P}<0.05)$ it induced higher $(\mathrm{P}<0.05)$ WHC (Miller, 2001). Table 2 shows the results of proximate composition and $\mathrm{pH}$ of beef. Moisture content and $\mathrm{pH}$ were lower $(\mathrm{P}<0.05)$ in treatment 3 , while crude protein and nitrogen free extract $(\mathrm{NFE})$ were higher $(\mathrm{P}<0.05)$ compared with those of other treatments. There were no significant $(\mathrm{P}>0.05)$ effects of organic acids used on fat and ash contents of meat samples across all the treatments in this study. High protein content and NFE in treatment 3 could be attributed to low moisture content and $\mathrm{pH}$ which might have prevented protein denaturation and nitrogen degradation by either intrinsic enzymes (catepsins) or microorganisms (Koohmaraie et al., 2005).

Therefore, high $\mathrm{pH}$ observed in treatment 1 and 4 could predispose the meat samples to spoilage and shorter shelf-life (Bucchman \& Golden, 1994). Lipid oxidation (TBA) was higher $(\mathrm{P}<0.05)$ in treatment 1 than in treatments 2,3 , and 4 while $(\mathrm{mPV})$ was higher $(\mathrm{P}<0.05)$ in treatment 1 followed by treatment 2 and was lower $(\mathrm{P}<0.05)$ in treatments 2 and 3 respectively (Table 3$)$. The high values of TBA and mPV observed in treatments 1 and 4 followed the patterns of WHC and moisture contents of the meat samples. Fat degrading enzymes are more active when moisture and $\mathrm{pH}$ are high in meat (Decker \& Crum, 1991) therefore, the results of lipid oxidation obtained in this study corroborated that of the previous workers as meat samples in treatments 1 and 4 were prone to oxidative rancidity than meat samples in treatments 2 and 3. Table 4 presented the microbial load of beef meat preserved with organic acids. Treatment 1 had highest $(\mathrm{P}<0.05)$ Aerobic bacteria count (staphylococcus) $\left(6.5 \times 10^{6}\right)$ followed by treatment $4\left(5.9 \times 10^{6}\right)$, while treatment 3 had lowest $(\mathrm{P}<0.05)$ staphylococcus count of $3.5 \times 10^{6}$. Treatment 3 had the least $(\mathrm{P}<0.05)$ enterobacteria count (enterobacter spp.) of $3.2 \times 10^{3}$ while treatment 1 had the highest $(\mathrm{P}<0.05)$ with $5.4 \times 103$ count followed by treatment 4 with $4.5 \times$ $10^{3}$ count. Moisture contents and $\mathrm{pH}$ of meat samples in treatment 1 and 5 were high which might have led to high microbial counts while, those of meat samples in treatments 2 and 3 were low thereby discouraged high population of both staphylococcus and enterobacter spp. in the meat samples. (Young \& Fregeding, 1993). Lactic acid bacteria (Lactobacillus spp.) (LAB) count was higher $(\mathrm{P}<0.05)$ in treatment 3 , followed by treatment 2 , while it was lower $(\mathrm{P}<0.05)$ in treatments 1 and 4 . This was possible probably LAB could thrive well in acidic medium than other two species of bacterial and therefore, out growed rapidly other species in the meat (Lee \& Yoon, 2001). They opined that under anaerobic conditions the growth of LAB was favoured against aerobic bacteria thereby extending the shelf-life of the meat. Similar results were observed in this study aerobic bacteria counts were higher in treatments 1 and 4, while those of LAB were lower, but LAB counts were higher in treatments 3 and 2, while those of aerobic bacteria were lower, hence, spoilage of meat samples in these treatments was not as high as observed in TBA and $\mathrm{mPV}$ of meat samples in treatments 1 and 4 . Cooked meat colour was higher $(\mathrm{P}<0.05)$ in treatment 1 and least $(\mathrm{P}<0.05)$ in treatments 3 . The results agreed with (Mikel et al., 1996) who reported that acetic acid deteriorated the surface colour of meat. Treatment 3 gave the meat samples lower $(\mathrm{P}<0.05)$ odour and ropinessscores against treatment 5 with higher $(\mathrm{P}<0.05)$ scores. However, flavour, tenderness, juiciness, cohesiveness and overall acceptability scores were higher $(\mathrm{P}<0.05)$ in treatment 1 while treatment 3 had the least $(\mathrm{P}<0.05)$ scores of these attributes. The lower overall acceptability of meat samples in treatment 3 could be borne out of the fact that it had lower colour and flavour which are the most cherished attributes of meat by consumers. 
Table 1. Physical attributes of preserved fresh beef meat as affected by organic acids

\begin{tabular}{llllll}
\hline Treatments & & & & & \\
Variable & T1 & T2 & T3 & T4 & SEM \\
\hline Raw meat colour & $6.55^{\mathrm{a}}$ & $5.21^{\mathrm{b}}$ & $4.00^{\mathrm{c}}$ & $5.00^{\mathrm{b}}$ & 2.41 \\
Cooking loss (\%) & $38.90^{\mathrm{a}}$ & $27.90^{\mathrm{c}}$ & $20.70^{\mathrm{d}}$ & $30.40^{\mathrm{b}}$ & 1.69 \\
Cooking yield (\%) & $61.10^{\mathrm{d}}$ & $72.10^{\mathrm{b}}$ & $79.30^{\mathrm{a}}$ & $69.60^{\mathrm{c}}$ & 1.02 \\
Thermal shortening (\%) & $36.80^{\mathrm{a}}$ & $25.60^{\mathrm{c}}$ & $18.60^{\mathrm{d}}$ & $27.20^{\mathrm{b}}$ & 1.94 \\
Drip loss (\%) & $52.00^{\mathrm{a}}$ & $40.00^{\mathrm{c}}$ & $30.00^{\mathrm{d}}$ & $45.00^{\mathrm{b}}$ & 1.28 \\
Water holding capacity (\%) & $65.00^{\mathrm{a}}$ & $49.10^{\mathrm{c}}$ & $43.00^{\mathrm{d}}$ & $53.00^{\mathrm{b}}$ & 1.35 \\
Shear force $\left(\mathrm{kg} / \mathrm{cm}^{3}\right)$ & $5.26^{\mathrm{b}}$ & $6.52^{\mathrm{a}}$ & $6.30^{\mathrm{a}}$ & $6.25^{\mathrm{a}}$ & 2.37 \\
\hline
\end{tabular}

abcd: Means on the same row with different superscripts are statistically significant $(\mathrm{P}<0.05)$.

Table 2. Proximate composition and $\mathrm{pH}$ of preserved fresh beef meat as influenced by organic acids

\begin{tabular}{llllll}
\hline Treatments & & & & & \\
Variable & T1 & T2 & T3 & T4 & SEM \\
\hline Moisture (\%) & $73.00^{\mathrm{a}}$ & $72.00^{\mathrm{b}}$ & $70.00^{\mathrm{c}}$ & $72.60^{\mathrm{ab}}$ & 1.63 \\
Crude Protein (\%) & $15.30^{\mathrm{c}}$ & $16.55^{\mathrm{b}}$ & $17.80^{\mathrm{a}}$ & $16.40^{\mathrm{b}}$ & 2.06 \\
Either Extract (Fat) (\%) & 2.70 & 2.60 & 2.60 & 2.70 & 6.06 \\
Ash (\%) & 0.90 & 0.80 & 0.80 & 0.90 & 0.10 \\
NFE (\%) & $7.60^{\mathrm{b}}$ & $8.05^{\mathrm{ab}}$ & $8.80^{\mathrm{a}}$ & $7.40^{\mathrm{b}}$ & 4.06 \\
pH & $6.87^{\mathrm{a}}$ & $4.76^{\mathrm{c}}$ & $4.50^{\mathrm{c}}$ & $5.80^{\mathrm{b}}$ & 1.20 \\
\hline
\end{tabular}

abcd: Means on the same row with different superscripts are statistically significant $(\mathrm{P}<0.05)$.

NFE $=$ Nitrogen Free Extract.

Table 3. Lipid oxidation of preserved fresh beef meat as influenced by organic acids

\begin{tabular}{llllll}
\hline $\begin{array}{l}\text { Treatments } \\
\text { Variable }\end{array}$ & $\mathrm{T} 1$ & $\mathrm{~T} 2$ & $\mathrm{~T} 3$ & $\mathrm{~T} 4$ & SEM \\
\hline TBA $(\mathrm{ug} / \mathrm{g})$ & $0.02^{\mathrm{a}}$ & $0.01^{\mathrm{b}}$ & $0.01^{\mathrm{b}}$ & $0.01^{\mathrm{b}}$ & 0.11 \\
$\mathrm{mPV}(\mathrm{mEq})$ & $0.30^{\mathrm{a}}$ & $0.20^{\mathrm{c}}$ & $0.20^{\mathrm{c}}$ & $0.21^{\mathrm{b}}$ & 0.48 \\
\hline
\end{tabular}

abc: Means on the same row with different superscripts are statistically significant $(\mathrm{P}<0.05)$.

TBA $=$ ThiobarBaturicAcid, MPV $=$ Modified Peroxide Value,$T V A=$ Total Volatile Acids.

Table 4. Microbial load of preserved fresh beef meat as influenced by organic acids

\begin{tabular}{lcccc}
\hline $\begin{array}{l}\text { Treatments } \\
\text { Variable }\end{array}$ & $\mathrm{T} 1$ & $\mathrm{~T} 2$ & $\mathrm{~T} 3$ & \multicolumn{2}{c}{$\mathrm{T} 4$} \\
\hline $\begin{array}{l}\text { Aerobic Bacteria } \\
\text { (Staphylococcus) }\end{array}$ & $6.5 \times 10^{6} \mathrm{a}$ & $4.7 \times 10^{6} \mathrm{~b}$ & $3.5 \times 10^{6} \mathrm{~d}$ & $5.9 \times 10^{6} \mathrm{~b}$ \\
$\begin{array}{l}\text { Enterobacteria } \\
\text { (Enterobacter spp.) }\end{array}$ & $5.4 \times 10^{3} \mathrm{a}$ & $4.3 \times 10^{3} \mathrm{~b}$ & $3.2 \times 10^{3} \mathrm{c}$ & $4.5 \times 10^{3} \mathrm{~b}$ \\
$\begin{array}{l}\text { Lactic Acid Bacteria } \\
\text { (Lactobacillus spp.) }\end{array}$ & $4.2 \times 10^{3} \mathrm{c}$ & $5.2 \times 10^{3} \mathrm{~b}$ & $6.3 \times 10^{3} \mathrm{a}$ & $4.9 \times 10^{3} \mathrm{~b}$ \\
\hline
\end{tabular}

abc: Means on the same row with different superscripts are statistically significant $(\mathrm{P}<0.05)$. 
Table 5. Sensory Properties preserved fresh beef meat as affected by organic acids

\begin{tabular}{llllll}
\hline Treatments & & & & & \\
Variable & $\mathrm{T} 1$ & $\mathrm{~T} 2$ & $\mathrm{~T} 3$ & $\mathrm{~T} 4$ & SEM \\
\hline Cooked meat colour & $7.00^{\mathrm{a}}$ & $6.00^{\mathrm{b}}$ & $4.21^{\mathrm{d}}$ & $5.30^{\mathrm{c}}$ & 2.37 \\
Odour & $5.00^{\mathrm{a}}$ & $3.20^{\mathrm{c}}$ & $3.00^{\mathrm{c}}$ & $4.10^{\mathrm{b}}$ & 2.24 \\
Flavour & $6.89^{\mathrm{a}}$ & $5.40^{\mathrm{b}}$ & $4.21^{\mathrm{c}}$ & $4.37^{\mathrm{c}}$ & 2.40 \\
Tenderness & $6.80^{\mathrm{a}}$ & $5.45^{\mathrm{b}}$ & $5.20^{\mathrm{b}}$ & $5.60^{\mathrm{b}}$ & 2.81 \\
Juiciness & $6.11^{\mathrm{a}}$ & $4.55^{\mathrm{b}}$ & $4.35^{\mathrm{b}}$ & $4.59^{\mathrm{b}}$ & 2.16 \\
Ropiness & $7.40^{\mathrm{a}}$ & $5.30^{\mathrm{c}}$ & $4.10^{\mathrm{d}}$ & $6.20^{\mathrm{b}}$ & 2.04 \\
Cohesiveness & $7.60^{\mathrm{a}}$ & $6.40^{\mathrm{b}}$ & $5.20^{\mathrm{c}}$ & $6.00^{\mathrm{b}}$ & 2.01 \\
Overall acceptability & $7.89^{\mathrm{a}}$ & $6.72^{\mathrm{b}}$ & $4.50^{\mathrm{d}}$ & $5.60^{\mathrm{c}}$ & 2.02 \\
\hline
\end{tabular}

abcd: Means on the same row with different superscripts are statistically significant $(\mathrm{P}<0.05)$.

Sensory scores were obtained on a 9-point Hedonic scale where 1 extremely dislike and $9=$ extremely like.

\section{Conclusion}

Fresh beef has high energy and unique biological and chemical properties. However,its nutrients composition represents an optimum medium for microbial growth such that it undergoes deterioration progressively from slaughter until consumption. There is the need therefore for extending the shelf-life of fresh beef cuts, one of the means of extending the shelf-life of beef is by using organic acids. In this study three dietary organic acids were tested viz- citric acid, acetic acid and ascorbic acid while cold preservation (freezing) was used as control since electricity current was supplied throughout the experimental period. It was observed that most of the meat attributes were better in meat samples preserved with 5\% acetic acid with exception of colour and flavour which might have contributed to low acceptability of meat sample preserved with the acid. Since other meat attributes were far better in meat preserved with 5\% acetic acid, it is hereby recommended that acetic acid should be used in preserving fresh beef and that lower levels of acetic acid be tested in another study to assess the best percentage level that will confer high acceptability on beef preserved using dietary acetic acids.

\section{References}

Abril, M., Campo, M. M., Onenc, A., Samudo, C., Albert, P., \& Neguemela, A. I. (2002). Beef Colour evolution as a function of ultimate pH. J. Meat Sci., 58, 69-78. http://dx.doi.org/10.1016/S0309-1740(00)00133-9

Acutt, G. R. (2005). Chemical decontamination strategies for meat. In: Improving the safety of Fresh Meat In J. N. Sofos (Ed.) (pp. 351-363). N.Y.: Wood head Pubilshing Limited, CRC Press.

APHA. (1992). Compendium of Method for the Microbiological Examination of Foods (3rd ed.) Ame. Public Health Ass. In C. Vanderzant \& F. S. Stoesser (Eds) U.S.A. Retrieved from http:// www.apha.org

AMSA. (1991). Guidelines for Meat colour evaluation Ame. Meat Sci. Assoc. Committee on Guidelines for Meat colour Evaluation. Proc. of the Reciprocal Meat Conf. Vol. 44. Retrieved from http://www.meatscience.org

AMSA. (1995). Research Guidelines for Cookery, Sensory Evaluation and Instrumental Measurement of Fresh meat. National Livestock and Meat Board. Chicago, IL, USA.

AOAC. (2000). Official methods of Analysis (19th ed.) (p. 1219). AOAc Inter, Inc. Washington, D.C.

Buchanan, R. L., \& Golden, M. A. (1994), Interaction of Citric acid concentration and pH on the Kinetics of Listeria Monocytogenes inactivation. J. Food Protec, 57, 567-570.

Decker, E. A., \& Crum, A. D. (1991). Inhibition of oxidative rancidity in salted ground pork by carnosine. $J$. Food Sci., 56, 1179-1181. http://dx.doi.org/10.1111/j.1365-2621.1991.tb04728.x

Dubal, Z. B., Paturkar, A. M., Waskar, V. S., Zende, R. J., Latha, C., Rawool, D. B., \& Kadam, M. M. (2004). Effect of food grade organic acids on inoculated S. aureus, L.monocytogenes, E. coli and S. typhimurium in sheep/goat meat stores at refrigeration temperature. Meat Sci., 66, 817-821. http://dx.doi.org/10.1016/j.meatsci.2003.08.004 
Honikel, J. L. (1998). Reference Methods for the assessment of physical characteristics of meat. Meat Sci., 49, 447-457. http://dx.doi.org/10.1016/S0309-1740(98)00034-5

Houben, J. H., VanDijk, A., Eikelenboom, G., \& Hoving-Bolink, A. H. (2000). Effect of dietary vitamin E supplementation, fat level and packaging on colour stability and lipid oxidation in mince beef. J. Meat Sci., 55, 331-336. http://dx.doi.org/10.1016/S0309-1740(99)00161-8

ICMSF. (1986). Microorganisms in Food 2. Sampling for Microbiological Analysis. Principles and Specific Application (2nd ed.), Canada: University of Toronto Press.

Insausti, K., Beriain, M. J., Purroy, A., Alberti, P., Gorraiz, C., \& Alzueta, M. J. (2001). Shelf-life of beef from different Spanish native cattle breeds stored under vacuum and modified atmosphere. Meat Sci., 57, 273-281. http://dx.doi.org/10.1016/S0309-1740(00)00102-9

Koohmaraie, M., Arthur, T. M., Bosilevac, J. M., Guerini, M., Shackelford, S. D., \& Wheeler, T. L. (2005). Post-harvest Interventions to reduce/eliminate pathogens in beef. Meat Sci., 71, 79-91. http://dx.doi.org/10.1016/j.meatsci.2005.03.012

Lebert, I., Baucour, P., Lebert, A., \& Daudin, J. D. (2005). Assessment of bacterial growth on the surface of meat under common processing conditions by combining biological and physical models. J. Food Eng, 68, 89-98. http://dx.doi.org/10.1016/j.jfoodeng.2004.05.026

Lee, K. T., \& Yoon, C. S. (2001). Quality changes and shelf-life of imported vacuum. Packaged beef chuck during storage at $0{ }^{\circ} \mathrm{C}$. Meat Sci., 59, 71-77. http://dx.doi.org/10.1016/S0309-1740(01)00054-7

Malgorzata, S., Kazimierz, L., Henry, K. K., Jrry, W., Leszek, G., Joanna, Z., ... Edyta, R. (2005). The effect of cattle genotype on texture of selected muscles during post-mortem ageing. Elec. J. Pol. Agric. Univ. Food Sci. and Tech., 8(3), 1-9.

Marchiori, A. F., \& DeFelicio, P. E. (2003). Quality of wild boar meat and commercial Pork. Sci. Agric. (Piracicaba, Braz), 60(1), 1-10.

Miller, R. K. (2001). Beef Flavour: A white paper. National Cattlemens' Beef Association, Centennial, CO.

Mikel, W. B., Goddnord, B. L., \& Bradford, D. D. (1996). Muscle Microstructure and Sensory attributes of

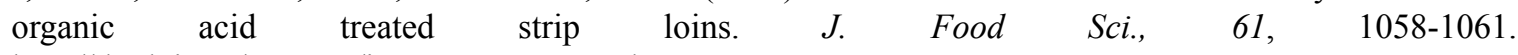
http://dx.doi.org/10.1111/j.1365-2621.1996.tb10932.x

Mohamed, B., Jamilah, K. A., A., \& Abdul Rahman, R. (2008). A Review on some Organic Acids Addictives as Shelf-Life Extenders of Fresh Beef cuts. Ame. J. Agric. and Biol. Sci., 3(3), 566-578. http://dx.doi.org/10.3844/ajabssp.2008.566.574

Omojola, A. B. (2008). Yield and Organoleptic characteristics of suya (an intermediate moisture meat) prepared from three different muscles of a matured bull. Afr. J. Biotech., 7(13), 2254-2257.

Pensel. (1990). Influence of Experimental Conditions on porcine muscle and its effect on oxidation. Msc. Thesis. Department of Animal Sciences. The Ohio State University, Columbus, Ohio, U.S.A.

Qiaofen, C., \& Da-Wen, S. (2005). Application of PLSR in correlating physical and chemical properties of pork ham with different cooking methods. Meat Sci., 70, 691-698. http://dx.doi.org/10.1016/j.meatsci.2005.03.004

Ramirez, A. J., Acuff, G. R., Lucia, L. M., \& Savell, J. W. (2001). Lactic acid and trisodium phosphate treatment of lamb breast to reduce bacterial contamination. J. Food Protec., 64, 1439-1441.

Ransom, J. R., Belk, K. E., Sofos, J. N., Stopforth, J. D., Scanga, J. A., \& Smith, G. C. (2003). Comparison of intervention technologies for reducing Escherichia coli 0157:117 on beef cuts and trimmings. Food Protec. Trends, 23, 24-34.

SAS. (2002). Statistical Analysis System. SAS Stat. Version 9, SAS Institute Inc. Garry, N.C; USA.

Shahidi, F. (1994). Assessment of lipid oxidation and off-Flavour Development in Meat and Meat Products. In F. Shahidi (Ed) Flavour of Meat and Meat Products. (p. 53). Blackie Academic and Professional, London UK. http://dx.doi.org/10.1007/978-1-4615-2177-8_1

Stopforth, J. D., \& Sofos, J. N. (2006). Recent Advances in Pre and Post-slaughter intervention strategies for control of meat contamination. In V. J. Juneja, J. P. Cherry \& M. H. Tunick (Eds) Advances in Microbial Food Safety, ACS symposium 931. Recent Advances in intervention strategies to improve food safety (pp. 66-86). Washington D.C.: Ame. Chem.Soc; Oxford University Press. 
Suzuki, A., Kaima, N., \& Ikeuchi, Y. (1991). Carcass Composition and meat quality of Chinese purebred and Euopean x Chinese cross bred pigs. Meat Sci., 29, 31-41. http://dx.doi.org/10.1016/0309-1740(91)90021-H

Wicklund, S. E., Stetzer, A. J., Tucker, E. M., Nicolalde, C. L., \& Brewer, M. S. (2005). Microbiological characteristics of enhancement solutions. J. Food Sci., 70, 296-300. http://dx.doi.org/10.1111/j.1365-2621.2005.tb11450.x

Young, K. M., \& Foegeding, P. M. (1993). Acetic, Lactic and Citric acids and pH Inlubition of Listeria Monocytogenes Scott A and the effect on Intracellular pH. J. Applied Bacterial., 74, 515-520.

\section{Copyrights}

Copyright for this article is retained by the author(s), with first publication rights granted to the journal.

This is an open-access article distributed under the terms and conditions of the Creative Commons Attribution license (http://creativecommons.org/licenses/by/3.0/). 